\title{
PREDICTING STUDENT'S CHOICE OF HOSTEL: AN APPLICATION OF MULTINOMIAL LOGISTIC REGRESSION
}

\author{
Kassim Korah Nantomah ${ }^{* 1}$, Baako Haruna ${ }^{2}$, Joseph Kunibara Kaba ${ }^{3}$ \\ ${ }^{* 1}$ Department of Statistics, Bolgatanga Polytechnic, Ghana
}

DOI: https://doi.org/10.29121/IJOEST.v2.11.2017.04

\begin{abstract}
Choice of hostel is a crucial decision to every student in tertiary education institution in Ghana. Government hitherto provides hostels for students, but due to limited resources of the state, private sector investors now support government. This creates an opportunity for students to decide which hostel to choose. Student's choice of hostel is influenced by several factors, but this study focused on only student's background variables. The study used multinomial logistic regression to predict student's choice of hostel in Ghanaian polytechnics. A simple random sample of 300 students was selected from Bolgatanga Polytechnic for the study. The selected students responded to a questionnaire that sought data on their background variables. The data was analyzed using SPSS Version 16.0. The results showed that male students exhibit significant preference for Local House to Private Hostel than female students. Significance preference was also shown for Private Hostel and Polytechnic Hostel to Local House by students with literate mothers. In addition, students from low income families also show significant preference for Local House to Private Hostel than their fellows from high income families. The results further established another significant prediction that students who have relationship problems with other students prefer Local House to Private and Polytechnic Hostels. The study recommends that management should consider students with illiterate mothers in Polytechnic Hostel first and also strengthen school-community relationship since some students prefer Local Houses to Polytechnic and Private Hostels.
\end{abstract}

Keywords: Choice; Hostel; Logistic; Multinomial; Private.

Cite This Article: Kassim Korah Nantomah, Baako Haruna, and Joseph Kunibara Kaba. (2017). PREDICTING STUDENT'S CHOICE OF HOSTEL: AN APPLICATION OF MULTINOMIAL LOGISTIC REGRESSION. International Journal of Engineering Science Technologies, 2(1), 28-36. doi: 10.29121/IJOEST.v2.i1.2017.04

\section{INTRODUCTION}

Enrolment into tertiary education institutions is seen as the fastest growing sector globally (Sharma, 2012). The growth rate stands at 6\% between 2002 and 2009 and about 160\% increase in enrolment since 1990. In Ghana, the demand for tertiary education continues to increase steadily. This may be attributed to policy initiatives; such as the Capitation Grants, the School Feeding Programme and the Free School Uniform put in place by successive governments to increase enrolment, retention and completion rate in the pre-tertiary levels of education. Tertiary education enrolment in Ghana increased averagely by $47.4 \%$ between 2010/2011 and 2014/2015 academic years (MOE, 2016). 
Government hitherto was responsible for providing hostels for students in tertiary institutions, but due to the phenomenal increases in enrolment couple with limited resources of the state, many tertiary institutions now have policies that allow private individuals to invest in providing hostels for students for the past two decades. As such, most tertiary institutions have developed guidelines regarding allocation of students to hostels. In Bolgatanga Polytechnic for instance, students are assigned to the Polytechnic hostel based on "first come, first served" until the hostel space is exhorted. The remaining majority of the students would have to find places in either a nearby private hostel or local house in the community.

The involvement of the private sector players in the provision of hostels for students in the tertiary institutions provided an opportunity for them to choose their preferred hostels. Subsequently, various studies have been conducted by researchers to explore the factors that predict student's choice of hostel in Ghana and beyond. Notably among them are Mahama, Boahen, Saviour and Tumaku (2016), Nimako and Bondinuba (2013) and Zotorvie (2017). Their studies unanimously identified security issues, availability of water, electricity, toilet facilities, study area, and peaceful environment, proximity to lecture halls, spacious, and well ventilated rooms, and hostel fee as the major factors that determine student's choice of hostel in tertiary institutions. However, their studies do not considered the influence of student's background variables on their choice of hostels. It is on this basis that this study used multinomial logistic regression to predict the effects of student's background variables on choice of hostel in Bolgatanga Polytechnic.

\section{MATERIALS AND METHODS}

A simple random sampling technique was used to obtain a sample of 300 Higher National Diploma students of Bolgatanga Polytechnic for the study. The data was collected using questionnaire and analyzed with the aid of SPSS Version 16.0. Multinomial logistics regression was ran to predict student's choice of hostel in Bolgatanga Polytechnic. The general significance and fitness of the model to the data were determined by Chi-Square Statistic and Cox \& Snell and Nagelkerke respectively. The response variable in this study has three nominal levels (Polytechnic Hostel, Private Hostel and Local House), hence multinomial logistic regression is deemed more applicable to the problem (Hosmer \& Lemeshow, 2000; Agresti, 2007). The estimates of the parameters in multinomial logistic regression were identified and compared to a baseline-category or reference category of the depend variable (Long, 1997).

The baseline-category logit model with predictor variable $\mathrm{x}$ is:

$$
\log \left(\frac{\pi_{j}}{\pi_{J}}\right)=\alpha_{j}+\beta_{j} x_{i} \quad j=1,2,3, \ldots, J-1
$$

The model has $J-1$ logit equations which are fit simultaneously. The outcome variable is categorized into Polytechnic Hostel, Private Hostel and Local House. Local House serves as the reference category.

Let $y_{j}$ represent student's choice of hostel, where $j=1,2,3$ thus;

$Y_{1}=$ Polytechnic Hostel

$Y_{2}=$ Private Hostel

$Y_{3}=$ Local House 
Let $P_{i j}=$ The probability that the $i^{t h}$ student will choose the $j^{\text {th }}$ hostel.

Where $i=1,2,3 \ldots \ldots . .300$. Then the two logit equations are as follows;

$$
\begin{aligned}
& \log \left(\frac{p\left(y_{i}=1 \mid x_{i} \operatorname{sex}+\cdots+x_{i} R S\right.}{p\left(y_{i}=3 \mid x_{i} \operatorname{sex}+\cdots+x_{i} R S\right.}\right)=\beta_{0}+\beta_{1} x_{i} \operatorname{sex}+\cdots+\beta_{7} x_{i} R S \ldots \\
& \log \left(\frac{p\left(y_{i}=2 \mid x_{i} \operatorname{sex}+\cdots+x_{i} R S\right.}{p\left(y_{i}=3 \mid x_{i} \operatorname{sex}+\cdots+x_{i} R S\right.}\right)=\beta_{10}+\beta_{12} x_{i} \operatorname{sex}+\cdots+\beta_{17} x_{i} R S
\end{aligned}
$$

Equations (2) and (3) give the odd ratios of a student choosing Polytechnic Hostel and Private Hostels relative to Local House. Their corresponding probability equations (4), (5) and (6) are:

$\mathrm{P}_{\mathrm{i}}$, Polytechnic Hostel $=\frac{e^{B_{1} x_{i}}}{1+\sum_{j=1}^{3} e^{B_{j} x_{i}}}$

$\mathrm{P}_{\mathrm{i}}$, Private Hostel $=\frac{e^{B_{2} x_{i}}}{1+\sum_{j=1}^{3} e^{B_{j} x_{i}}}$

$\mathrm{P}_{\mathrm{i}, \text { Local Hostel }}=\frac{e^{B_{3} x_{i}}}{1+\sum_{j=1}^{3} e^{B_{j} x_{i}}}$

The predictor variables as captured in the logit equations (2) and (3) are sex and age of the student, mother's education (ME), family size (FS), family income (FI) and health status (HS) of student, and student relationship with other students(RS).

\section{RESULTS AND DISCUSSION}

The study used multinomial logistic regression to predict Bolgatanga Polytechnic Students' choice of hostels. The results of the study were presented and discussed here.

\subsection{Demographic Characteristics of Respondents}

The demographic characteristics of respondents were presented in Table 1.

Table 1: Demographic Characteristics of Respondents

\begin{tabular}{clll}
\hline Variables & & Frequency & Percentage (\%) \\
\hline \multirow{4}{*}{ Types of Hostel } & Polytechnic hostel & 80 & $26.70 \%$ \\
& Private hostel & 164 & $54.70 \%$ \\
& Local house & 56 & $18.70 \%$ \\
& Total & 300 & $100 \%$ \\
\hline \multirow{3}{*}{ Sex of student } & Male & 173 & $57.70 \%$ \\
& Female & 127 & $42.30 \%$ \\
& Total & 300 & $100 \%$ \\
\hline \multirow{3}{*}{ Students age } & $15-20$ years & 35 & $11.70 \%$ \\
& $21-26$ years & 206 & $68.70 \%$ \\
& 27 years above & 59 & $19.70 \%$ \\
& Total & 300 & $100 \%$ \\
\hline
\end{tabular}




\begin{tabular}{|c|c|c|c|}
\hline \multirow{3}{*}{ Mother's education } & Educated & 130 & $43.30 \%$ \\
\hline & Not educated & 170 & $56.70 \%$ \\
\hline & Total & 300 & $100 \%$ \\
\hline \multirow{4}{*}{ Family size } & $1-5$ people & 130 & $43.30 \%$ \\
\hline & 6-10 people & 119 & $39.70 \%$ \\
\hline & above 10 people & 51 & $17.00 \%$ \\
\hline & Total & 300 & $100 \%$ \\
\hline \multirow{4}{*}{ Family income } & Low & 44 & $14.70 \%$ \\
\hline & Average & 227 & $75.70 \%$ \\
\hline & High & 29 & $9.70 \%$ \\
\hline & Total & 300 & $100 \%$ \\
\hline \multirow{3}{*}{ Health status of student } & Always sick & 23 & $7.70 \%$ \\
\hline & Hardly sick & 277 & $92.30 \%$ \\
\hline & Total & 300 & $100 \%$ \\
\hline \multirow{4}{*}{$\begin{array}{l}\text { Relationship with other } \\
\text { students }\end{array}$} & Not cordial & 16 & $5.30 \%$ \\
\hline & Cordial & 163 & $54.30 \%$ \\
\hline & Very cordial & 121 & $40.30 \%$ \\
\hline & Total & 300 & $100 \%$ \\
\hline
\end{tabular}

It is indicated in Table 1 that, $57.7 \%$ of the respondents were males and the remaining $42.3 \%$ were females. About $12 \%$ of the respondents were between $15-20$ years, $68.7 \%$ of them were between 21-26 years and $19.7 \%$ of them were 27 years and above. Also, $43.3 \%$ of the respondents' mothers were educated while the remaining $56.7 \%$ were not. Approximately $43 \%$ of the respondents belong to families with family size ranging from $1-5$ people, $39.7 \%$ of them belong to families with family size ranging from 6-10 people and the remaining $17.0 \%$ of them belong to families with family size above 10 people. Also, about $76 \%$ of the respondents were from average income families, $14.7 \%$ of them were from low income families and the remaining $9.7 \%$ of them were from high income families. Approximately $92 \%$ of the respondents hardly fall sick, while the remaining $7.7 \%$ always fall sick. Majority $(54.3 \%)$ of the respondents had cordial relationship with other students, $40.3 \%$ of them had very cordial relationship with other students and only $5.3 \%$ of them do not had cordial relationship with other students.

\subsection{Multinomial Logistics Regression}

The overall measure of significance of the logistic regression model was assessed using the ChiSquare statistic. The results were presented in Table 2.

Table 2: Model Fitting Information

\begin{tabular}{lllll}
\hline Model & $\mathbf{- 2}$ Log Likelihood & Chi-Square & df & p-value \\
\hline Intercept Only & 372.016 & & & \\
Final & 313.406 & 58.610 & 22 & .000 \\
\hline
\end{tabular}

From Table 2, the Chi-Square; $\chi^{2}(313.406,22)=58.61, \mathrm{p}<0.000$ indicates a significant prediction of the dependent variable in the model. However, the Chi-Square statistic is deficient in showing the strength of the association between the predictor variables and the dependent variable; hence the Pseudo R-square measure was used and the results presented in Table 3. 
Table 3: Pseudo R-Square

\begin{tabular}{ll}
\hline Cox and Snell & 0.177 \\
Nagelkerke & 0.206
\end{tabular}

The Pseudo R-square can be interpreted as a measure of how well the model fits the data. The Cox and Snell value of $17.7 \%$ and the Nagelkerke value of $20.6 \%$ indicated a weak relationship between the dependent variable and predictors variables in the model. Both measures indicated that $17.7 \%$ and $20.6 \%$ of the variance are respectively predicted by the independent variables. The classification accuracy of the model was also assessed and presented in Table 4.

Table 4: Classification

\begin{tabular}{lllll}
\hline Observed & Predicted & & & \\
\cline { 2 - 5 } & $\begin{array}{l}\text { Polytechnic } \\
\text { Hostel }\end{array}$ & Private Hostel & Local House & $\begin{array}{l}\text { Percent } \\
\text { Correct }\end{array}$ \\
Polytechnic Hostel & 15 & 58 & 7 & $18.8 \%$ \\
Private Hostel & 7 & 154 & 3 & $93.9 \%$ \\
Local House & 3 & 41 & 12 & $21.4 \%$ \\
Overall Percentage & $8.3 \%$ & $84.3 \%$ & $7.3 \%$ & $60.3 \%$ \\
\hline
\end{tabular}

The model predicted $18.8 \%$ of the students that prefer Polytechnic Hostel correctly, 93.9\% of those who prefer Private Hostel correctly, and $21.4 \%$ of those who prefer Local House correctly. The overall prediction of the model is $60.3 \%$ (i.e. $60.3 \%$ of the students; choices were predicted correctly).

\subsection{The Multinomial Logit Models}

The study presents two multinomial logit equations with students' choice of Local House serving as reference category. The maximum likelihood method was used to calculate the parameter coefficients of the model. The first logit equation compared student's choice of Polytechnic Hostel to Local House and the second compared student's choice of Private Hostel to and Local House. Table 5 and Table 6 present the two logit models.

Table 5: Coefficients of Multinomial Logistic Regression-Polytechnic Hostel versus Local House

\begin{tabular}{|c|c|c|c|c|c|c|c|c|}
\hline \multicolumn{9}{|c|}{ Multinomial Logit Model } \\
\hline \multirow[t]{2}{*}{ Predictor variables } & \multirow[t]{2}{*}{ B } & \multirow[t]{2}{*}{ SE } & \multirow[t]{2}{*}{ Wald } & \multirow[t]{2}{*}{ df } & \multirow[t]{2}{*}{ P-value } & \multirow[t]{2}{*}{ Odds Ratio } & \multicolumn{2}{|c|}{$95 \%$ C.I for odds ratio } \\
\hline & & & & & & & Lower Bound & Upper Bound \\
\hline Intercept & 0.84 & 1.11 & 0.57 & 1 & 0.45 & & & \\
\hline Sex & & & & & & & & \\
\hline Male & -0.5 & 0.4 & 1.46 & 1 & 0.23 & 0.62 & 0.29 & 1.35 \\
\hline Female & $0^{\mathrm{b}}$ & . & . & 0 & . & . & . & . \\
\hline Age & & & & & & & & \\
\hline $15-20$ years & 0.54 & 0.84 & 0.41 & 1 & 0.52 & 1.72 & 0.33 & 8.88 \\
\hline $21-26$ years & 0.28 & 0.49 & 0.33 & 1 & 0.56 & 1.33 & 0.51 & 3.45 \\
\hline 27 years above & $0^{\mathrm{b}}$ & . & . & 0 & . & . & . & . \\
\hline
\end{tabular}

Mother's education 
Predicting Student's Choice of Hostel: An Application of Multinomial Logistic Regression

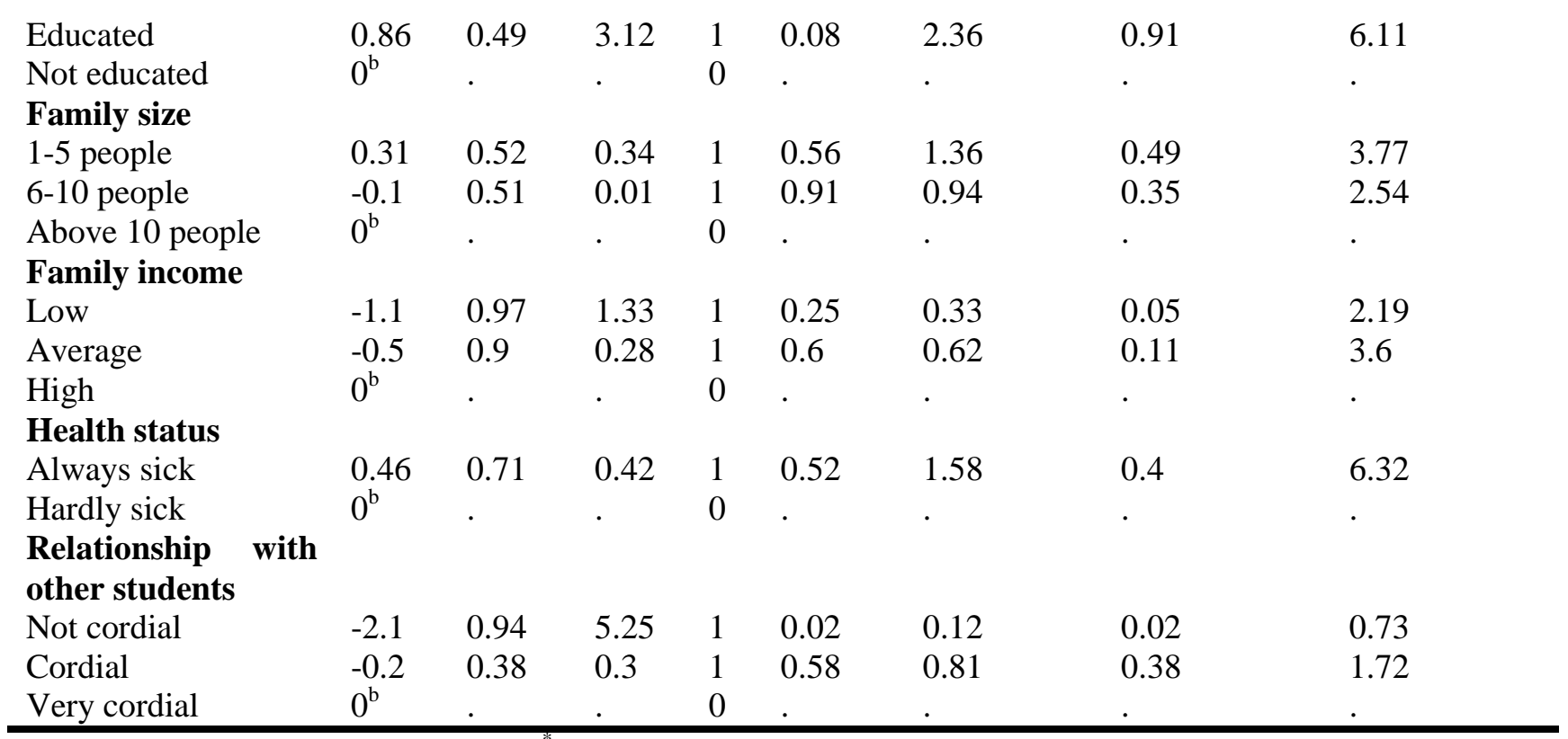

The reference category: Local House, "Significant categories at 0.05 probability level

From Table 5, male students were 0.62 times less likely to choose Polytechnic Hostel than female students relative to Local House, though not significant (0.23). The results also indicated that students between the ages of 15-20 years were 1.72 times more likely to choose Polytechnic Hostel as compare to students between the ages of 27 years and above relative to Local House. Also, students between the ages of 21-26 years were 1.33 times more likely to choose Polytechnic Hostel as compare to students between 27 years and above relative to Local House, though not significant. Students whose mothers are educated were found to be 2.36 times more likely to choose Polytechnic Hostel than their counterparts whose mothers are not relative to Local House with an insignificant value of 0.08 . The results further showed that students from family size of $1-5$ children were 1.36 times more likely to choose Polytechnic Hostel than their fellows from a family size of 10 children and above relative to Local House. Again, students from a family size of 10 children and above were 1.06 times more likely to choose Polytechnic Hostel than students from a family size of 6-10 people relative to Local House. It is shown in Table 5 that students from low and average income families were respectively 0.33 times and 0.62 times less likely to choose Polytechnic Hostel than students from high income families relative to Local House, though, not significant. Students who are always sick were 1.58 times more likely to choose Polytechnic Hostel against students who are hardly sick relative to Local House, though not significant. Finally students whose relationship with other student is not cordial were 0.12 times less likely to choose Polytechnic Hostel as compare to students whose relationship with other students is very cordial relative to Local House with 0.02 significance and students whose relationship with other students is cordial were 0.81 times less likely to choose Polytechnic Hostel than students whose relationship with other students is very cordial relative to Local House, though not significant. 
Table 6: Coefficients of Multinomial Logistic Regression-Private Hostel versus Local House

\begin{tabular}{|c|c|c|c|c|c|c|c|c|}
\hline \multirow{3}{*}{$\begin{array}{l}\text { Intercept and } \\
\text { Predictor variables }\end{array}$} & \multicolumn{8}{|c|}{ Multinomial logit model } \\
\hline & \multirow[t]{2}{*}{$\mathbf{B}$} & \multirow{2}{*}{$\overline{S E}$} & \multirow{2}{*}{ Wald } & \multirow{2}{*}{$\overline{d f}$} & \multirow[t]{2}{*}{ p-value } & \multirow{2}{*}{$\begin{array}{l}\text { Odds } \\
\text { Ratio }\end{array}$} & \multicolumn{2}{|c|}{ 95\% C.I for Odd Ratios } \\
\hline & & & & & & & $\begin{array}{l}\text { Lower } \\
\text { Bound }\end{array}$ & $\begin{array}{l}\text { Upper } \\
\text { Bound }\end{array}$ \\
\hline Intercept & 2.12 & 1.03 & 4.26 & 1 & 0.04 & & & \\
\hline Sex & & & & & & & & \\
\hline Male & -0.9 & 0.37 & 6.07 & 1 & 0.01 & 0.41 & 0.2 & 0.83 \\
\hline Female & $0^{\mathrm{b}}$ & . & . & 0 & . & . & . & . \\
\hline Age & & & & & & & & \\
\hline $15-20$ years & -0.2 & 0.79 & 0.07 & 1 & 0.79 & 0.81 & 0.17 & 3.81 \\
\hline 21-26 years & -0.2 & 0.42 & 0.27 & 1 & 0.6 & 0.81 & 0.36 & 1.82 \\
\hline 27 years above & $0^{\mathrm{b}}$ & 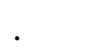 & . & 0 & . & . & • & . \\
\hline Mother's education & & & & & & & & \\
\hline Educated & 1.55 & 0.45 & 11.9 & 1 & 0.00 & 4.69 & 1.95 & 11.3 \\
\hline Not educated & $0^{\mathrm{b}}$ & . & . & 0 & . & . & . & • \\
\hline Family size & & & & & & & & \\
\hline 1-5 people & -0.1 & 0.48 & 0.01 & 1 & 0.92 & 0.95 & 0.37 & 2.45 \\
\hline 6-10 people & 0 & 0.45 & 0 & 1 & 0.99 & 0.99 & 0.41 & 2.42 \\
\hline Above 10 people & $0^{\mathrm{b}}$ & 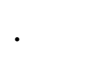 & . & 0 & . & . & 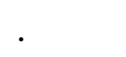 & - \\
\hline Family income & & & & & & & & \\
\hline Low & -1.9 & 0.92 & 4.2 & 1 & 0.04 & 0.15 & 0.03 & 0.92 \\
\hline Average & -0.7 & 0.84 & 0.67 & 1 & 0.41 & 0.5 & 0.1 & 2.62 \\
\hline High & $0^{\mathrm{b}}$ & . & . & 0 & . & . & . & . \\
\hline Health status & & & & & & & & \\
\hline Always sick & -0.7 & 0.73 & 0.95 & 1 & 0.33 & 0.49 & 0.12 & 2.06 \\
\hline Hardly sick & $0^{\mathrm{b}}$ & . & . & 0 & . & . & . & . \\
\hline $\begin{array}{l}\text { Relationship with } \\
\text { other students }\end{array}$ & & & & & & & & \\
\hline Not cordial & -1.4 & 0.72 & 3.82 & 1 & 0.05 & 0.24 & 0.06 & 1.01 \\
\hline Cordial & 0.3 & 0.36 & 0.7 & 1 & 0.4 & 1.35 & 0.67 & 2.73 \\
\hline Very cordial & $0^{\mathrm{b}}$ & & & 0 & & 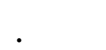 & & \\
\hline
\end{tabular}

The reference category: Local House, ${ }^{*}$ Significant categories at 0.05 probability level

The results indicated that male students were 0.41 times less likely to choose Private Hostel than their female counterparts relative to Local House at 0.01 level of significance. In other words, female students were 2.44 times more likely to choose Private Hostel relative to Local House with 0.01 level of significance. Though, not significant, students between the ages of 15-20 years and 21-26 years were respectively 0.81 times less likely to choose Private Hostel as against students between the ages of 27 years and above relative to Local House (see Table 6).

In addition, students whose mothers were educated were 4.69 more likely to choose Private Hostel as compare to their counterparts whose mothers were not relative to Local House with 0.00 level of significance. The results further showed that students whose families have 1-5 and 6-10 children were respectively 0.95 and 0.99 less likely to choose Private Hostel as compare to students whose family has 10 people and above relative to Local House, though not significant. 
As shown in Table 6, students from low income families were 0.15 times less likely to choose Private Hostel than their fellows from high income families relative to Local House with a significant level of 0.04. In other words, students from low income families were 6.67 times more likely to choose Local House compare to students from high income families relative to Private Hostel with 0.04 level of significance. Also, students from average income families were 2 times more likely to choose Local House as compare to their counterparts from high income families relative to Private Hostel, though not significant. Furthermore, students who are always sick were 0.49 times less likely to choose Private Hostel as compare to students who are hardly sick relative to Local House, though not significant. Also, students who do not have cordial relationship with other students were 0.24 times less likely to choose Private Hostel as compare to their counterparts who show very cordial relationship with others relative to Local House with a significant value of 0.05 . Finally, students who show cordial relationship with other students were 1.35 times more likely to choose Private Hostel as compare to their fellows with very cordial relationship relative to Local house, though not significant.

\section{CONCLUSION AND RECOMMENDATIONS}

The study used multinomial logistic regression to analyze the effects of student's background variables on choice of hostel in Ghanaian polytechnics. The results revealed that male students prefer staying in Local House to Private Hostel than female students. Also, student with literate mothers prefer living in Private Hostel to Local House than students with illiterate mothers. In addition, students from low income families will choose Local House at the expense of Private Hostel than their fellows from high income families. The results also showed that students who have relationship problems with other students prefer to stay in Local House to Private Hostel. Furthermore, students whose mothers are literates prefer Polytechnic Hostel to Local House. Moreover, students from low and average income families prefer Local House to Polytechnic Hostel, though not significant. Finally, students who have cordial relationship with other students prefer Polytechnic Hostel to Local House. All these findings serve as a repository of knowledge to guide policy makers, management of polytechnics and private investors the way forward regarding the provision of hostel facilities for students in the institutions of higher learning in Ghana. The study recommends that management should consider students with illiterate mothers in Polytechnic Hostel first and also strengthen school-community relationship since some students prefer staying in Local Houses to Polytechnic and Private Hostels.

\section{REFERENCES}

[1] Agresti Alan. (2007). "AN INTRODUCTION TO CATEGORICAL DATA ANALYSIS" (2nd ed.). New Jersey: John Wiley \& Sons, Inc. DOI.10.1002/0470114754.

[2] Hosmer David W. \& Lemeshow Stanley. (2000). "APPLIED LOGISTIC REGRESSION" (2nd ed.). New York: Wiley.DOI.10.1002/sim.1117.

[3] Long, J. Scott. (1997). "REGRESSION MODELS FOR CATEGORICAL AND LIMITED DEPENDENT VARIABLES”. Thousand Oaks, CA: Sage.http:doi.org/10.1086/231290.

[4] Mahama François, Boahen Patience Ama Nyantakyiwaa, Saviour Akuamoah Worlanyo and Tumaku John (2016). "MODELING SATISFACTION FACTORS THAT PREDICT STUDENTS CHOICE OF PRIVATE HOSTELS IN A GHANAIAN POLYTECHNIC" British Journal of Mathematics \& Computer Science, 19(3): XX-XX, 2016. Article metrics. DOI.10.9734/BJMCS/2016/29176. 
[5] Ministry of Education (2016). "EDUCATION SECTOR PERFORMANCE REPORT 2015, GHANA". http://www.moe.gov.gh>assets>media>docs.

[6] Nimako Simon Gyasi and Bondinuba Francis Kwesi (2013). "RELATIVE IMPORTANCE OF STUDENT ACCOMMODATION QUALITY IN HIGHER EDUCATION". Current Research Journal of Social Sciences 5(4): 134-142, 2013.

[7] Sharma, Y. (2012). "FAST PACE OF HIGHER EDUCATION ENROLMENT GROWTH PREDICTED TO SLOW". 13 March 2012 Issue No: 213. Retrieved on 20/5/2017 from http://www.universityworldnews.com/article.php?story=2012031308172724.

[8] Zotorvie, J.S.T. (2017). "STUDENTS' ACCOMMODATION AND ACADEMIC PERFORMANCE: THE CASE OF HO TECHNICAL UNIVERSITY, GHANA". European Scientific Journal, 13(13):290-302.http: dx. doi.org/10.19044/esj.2017.v13n13p290.

*Corresponding author.

E-mail address: nantomahk@yahoo.com 